\title{
Relationship of dietary browse to intake in captive muskoxen
}

\author{
CHAD S. BOYD, WILLIAM B. COLLINS, AND PHILIP J. URNESS
}

\begin{abstract}
Authors are graduate student, Zoology Department, Oklahoma State University, Stillwater, Okla. 74078-0459; bialogist. Alaska Department. of Fish and Game, Palmer, Alaska, 99645; professor, Range Science Department., Utah State University, Logan, Utah 84322-5230.
\end{abstract}

\begin{abstract}
The effect of dietary browse (Salix bebbiana Sarg.) on intake and activity of muskoxen (Ovibos moschatus Zimmermann) pastured in south-central Alaska was compared to animals on grass pasture only. In previous work, intake increased in penned animals fed increasing browse: hay rations, which presumably allowed for increased weight gain and wool fiber (qiviut) growth. Eight mature steers were divided into 2 treatments: 8 hours daily ad libitum access to browse plus pasture grass (Bromus inermis Leyss, Poa pratensis L. mix) or pasture grass only. Animals were placed in adaptation enclosures 10 days before each trial. Bundles of browse were tied to perimeter fences. Trials were conducted 3 times during the 1992 growing season. For the trials, 2 animals of like treatment were placed in each of four 0.33 ha trial enclosures for 8 hours, every other day, for 6 days ( 3 trial days). Activity budgets were calculated using scan sampling. Hand-harvested simulated bites were weighed to determine bite size, and bite rate was calculated using focal sampling techniques. Intake was calculated as a function of bite size, bite rate, and time spent foraging. Intake was greater $(P=0.064)$ for animals with access to browse. Digestive physiology of mukoxen may have favored higher intake of a mixed grass-browse diet over grass alone. Previous data suggest that elevated intake increases weight gain and qiviut growth.
\end{abstract}

Key Words: activity, captivity, pasture, Obivos moschatus

During summer 1991, we conducted research at the Musk Ox Farm, an experimental commercial enterprise in Palmer, Alaska. We investigated the influence of dietary browse on qiviut growth and weight gain in penned animals. Increased qiviut growth and weight gain were observed with increasing dietary ratios of browse:brome hay (Boyd 1993). Improved performance was apparently related to increased dry matter intake associated with increased dietary browse. However, implications of these results to the grazing animal remained untested. During the 1992 growing season, we tested the hypothesis that pastured animals with access to browse would have higher intakes than animals eating grass alone. We assumed that any increases in intake due to

This research was funded through combined grants from the Alaska Science and Teclunology Foundation and the Musk Ox Development Corporation.

Manuscript accepted 3 Mar. 1995. dietary browse would improve animal performance, as observed previously (Boyd 1993).

\section{Materials and Methods}

Six adjacent pastures were constructed for pasture browse trials: 2 adaptation pastures ( 0.66 ha each) and 4 trial pastures ( 0.33 ha each). Pasture grass consisted of a smooth brome (Bromus inermis Leyss.): Kentucky bluegrass (Poa pratensis L.) mix. Pasturcs were fenced with a combination of electric fence and heavy gauge net-wire.

Seven 5-year-old and one 6-year-old castrate muskox were used in the pasture browse trials. Each animal was assigned to 1 of 2 treatments: pasture grass alone (grass), or pasture grass with 8 hours daily ad libitum access to browse (grass/browse). Optimally, ad libitum browse would have been provided on a 24hour basis; however, this proved unfeasible due to the amount of time required to harvest the needed quantity of browse. Thus, the 8-hour exposure period was assumed to be a qualitatively representative index to 24 -hour intake and activity cycles. Each pasture browse trial was preceded by a 10-day adaptation period in which grass/browse treatment animals were maintained on grass and allowed the assigned access to browse, and grass treatment animals were maintained on grass. All animals in each treatment were maintained in one pasture for purposes of adaptation.

No browse was available at the study site, so it had to be harvested from a nearby collection site on a daily basis. Bebb willow (Salix bebbiana Sarg.), a highly preferred browse species (Boyd 1993), was used throughout the trial. Browse was placed on offer by cutting branches into lengths of about 1 meter, forming these sections into bundles, and tying the bundles into the net wire fencing. The cutting and display of browse in this manner was assumed not to have a significant effect on its chemical properties. Enough browse was offered to ensure that harvestable material remained 8 hours after being fed. Bundles were spaced far enough apart to minimize competitive interactions between animals.

\section{Experimental Design}

Trials were conducted 11-15 July, 2-6 August and 27-31 August 1992. Each trial period consisted of three 8-hour intake trials conducted on alternate days. Trials began 8 hours before 
sunset. For these trials, 2 animals of like treatment were placed in each trial pasture. It was necessary to pair animals of like hierarchical status (within treatments) to minimize dominance-related behavioral interactions. The same pairs were used in each trial period. Additionally, pairs of animals were always placed in the same pasture during trials, because of their tendency to become excitable when placed into a new pasture for the first time. All animals were put in their trial pastures for short periods preceding the first intake trial to ensure familiarity with their new surroundings during the first trial period.

Repeated measures ANOVA (SAS 1987) was used to detect treatment differences in intake and activity. If period by treatment differences in intake or feeding behavior were present, Fisher's L.S.D. procedures (SAS 1987) were used to determine their significance within and between trial periods. Pastures were treated as experimental units. The main effects of treatment and trial period were considered fixed, and pasture, animal, and day were random variables.

\section{Intake}

Intake was calculated as a function of feeding time, bite size, and bite rate (Collins et al. 1978). Rate of intake was calculated by multiplying bite rate by bite size in grams, for each bite rate class. For animals in the grass/browse treatment, browse intake during the first feeding period of each trial day was calculated separately from the remainder of the trial day (owing to variations in bite size), and the 2 values were summed to calculate total browse intake for each trial day. Eight-hour intake values for each trial day, for each animal, were divided by the animal's metabolic weight (body weight ${ }^{75}$ ) for that week and expressed as an average percent of metabolic weight intake, on a dry-matter basis.

\section{Activity}

Scan sampling (Altmann 1974) was used to determine activity budgets. Instantaneous observations of animal behavior were made at 10 -minute intervals by the same observer for the duration of each trial. Behavioral categories included: feeding (grass or browse), walking, lying, ruminating, standing, running, and other. Feeding behavior was considered to include active grazing, browsing, or searching activity.

\section{Bites}

Browse bites were hand-collected to represent bites taken during the first feeding bout of a trial day, bites taken thereafter, and stripping bites (animals frequently used a stripping motion when browsing). Thus, 3 browse bite sizes (bite 1, bite 2, and stripping) were calculated for browse. One average grass bite size was hand-collected, to be representative of both treatments. Mean bite sizes for each trial period were calculated by hand harvesting, drying, and weighing 150 representative bites in each category (Collins et al. 1978, Wickstrom et al. 1984). Bite sizes were taken to be representative of the treatment (i.e. no attempt was made to account for animal-to-animal variation in bite size).

Focal (Altmann 1974) bite counts were made throughout the 8hour trial to determine rate of browse and grass bites and browse stripping activity. Counts were made for 2.5 minutes for the first feeding bout, and for 5-minute periods for the remainder of each trial. If, during a focal period, an animal ceased foraging activity for longer than 30 seconds, a new focal animal was selected. The first pasture to be sampled was randomly selected from the four trial pastures, and the animal standing farthest north was sampled first. If this animal was not foraging, the other animal in the pasture was used. The observer then moved to a pasture of opposite treatment. When all pastures had been sampled, the observer would repeat the procedure using a new focal animal. Bites were defined as head motion involving successful removal of herbaceous material from grass or browse plants (i.e. chewing activity not counted). Bite rates were calculated separately for browse bites and strips during the first feeding bout, bites and strips thereafter, and for grass bites. The individual bite rate of each animal was used in calculating intake values, as opposed to using a treatment average.

\section{Nutrition}

Samples of pasture grass and browse were collected during each intake trial period for nutritional analysis. Additionally, samples of browse and grass were composited to represent the average diet chosen by the grass/browse treatment for each period. Samples were hand harvested to be representative of plant parts consumed by study animals. Browse samples included leaf material as well as a distal portion of current annual twig growth. Samples were oven dried at $40^{\circ} \mathrm{C}$ and ground through a Wiley Mill to pass a $0.5 \mathrm{~mm}$ mesh screen. Fiber, crude protein (CP), and in vitro dry matter digestibility (IVDMD) analyses were conducted at the Utah State University Range Nutrition Laboratory. Fiber analysis followed procedures outlined in Van Soest (1970) and CP content was determined using a modification of the Hach et al. (1985) micro-Kjeldal technique. In vitro dry matter digestibility analysis followed the Moore (1970) technique. Inoculum for the procedure was obtained from a ruminally cannulated Holstein cow maintained on a brome hay diet. The digestion procedure was initiated within 1 hour of inoculum collection.

\section{Results}

\section{Activity}

Only standing $(P=0.024)$ and feeding $(P=0.040)$ behaviors were different between treatments (Table 1), grass animals spending more time standing and grass/browse animals spending more time feeding. Time spent feeding was stratified by treatment and period (Fig. 1). While the period effect was not significant $(\mathrm{P}=$ 0.299 ), differences in feeding time between treatments, within period, were significant only in period $3(P<0.05)$ with the grass/browse animals spending more time feeding. The

Table 1. Average percent of total time muskoxen spent in different behaviors on grass-with-browse (GB) and grass (G) pastures, Palmer, Alaska, 1992.

\begin{tabular}{lccc}
\hline \hline Activity & GB & G & P \\
\hline & $(\%)$ & $(\%)$ & \\
Feed & 54.69 & 49.80 & .040 \\
Lie & 16.14 & 17.93 & .333 \\
Walk & .28 & 2.31 & .285 \\
Ruminate & 25.86 & 23.29 & .523 \\
Stand & 1.06 & 3.27 & .024 \\
Scratch & 1.92 & 1.35 & .737 \\
Run & - & .06 & .423 \\
Drink & .28 & .28 & .982 \\
\hline
\end{tabular}




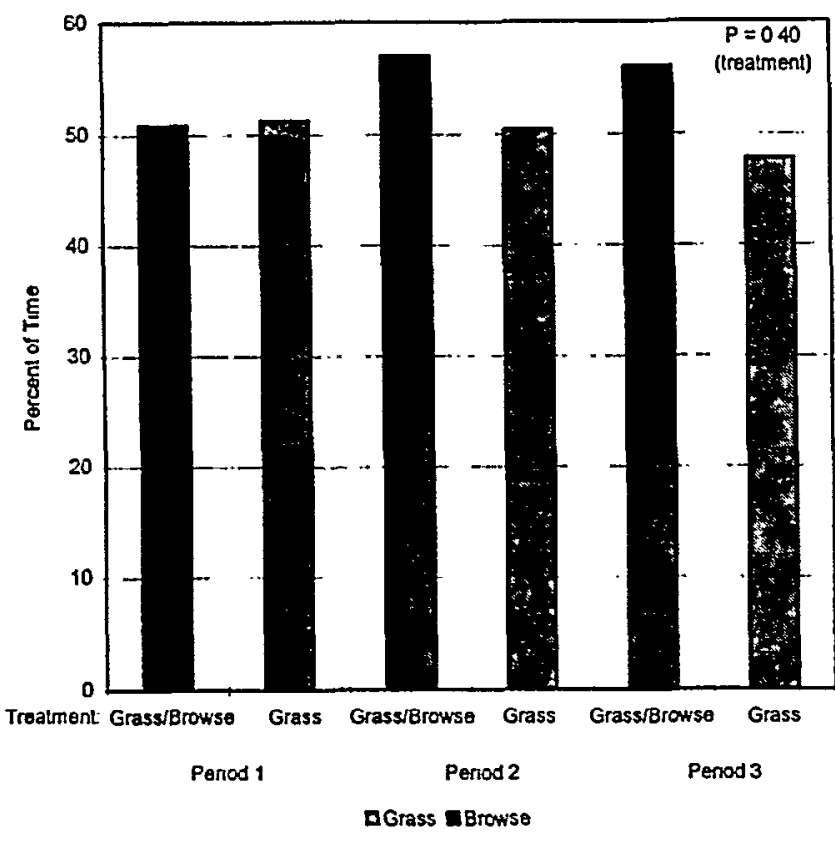

Fig. 1. Average percent of time muskoxen spent feeding on grass and browse by period, Palmer, Alaska, 1992.

grass/browse animals spent $58(\mathrm{SE}=2.5), 59(\mathrm{SE}=4.4)$, and $53 \%$ ( $\mathrm{SE}=1.3$ ) of their total feeding time feeding on browse in periods 1,2 , and 3 , respectively. Absolute time spent browsing varied by pasture $(P<0.001)$ and period $(P=0.003)$, with more time being spent browsing in period $2(\mathrm{P}<0.05)$ than in periods 1 or 3 .

\section{Bites}

For grass/browse animals browse bite size was largest during the first feeding bout of each trial (Fig. 2). Initial feeding bouts usually lasted about 1 hour. During initial bouts, grass/browse

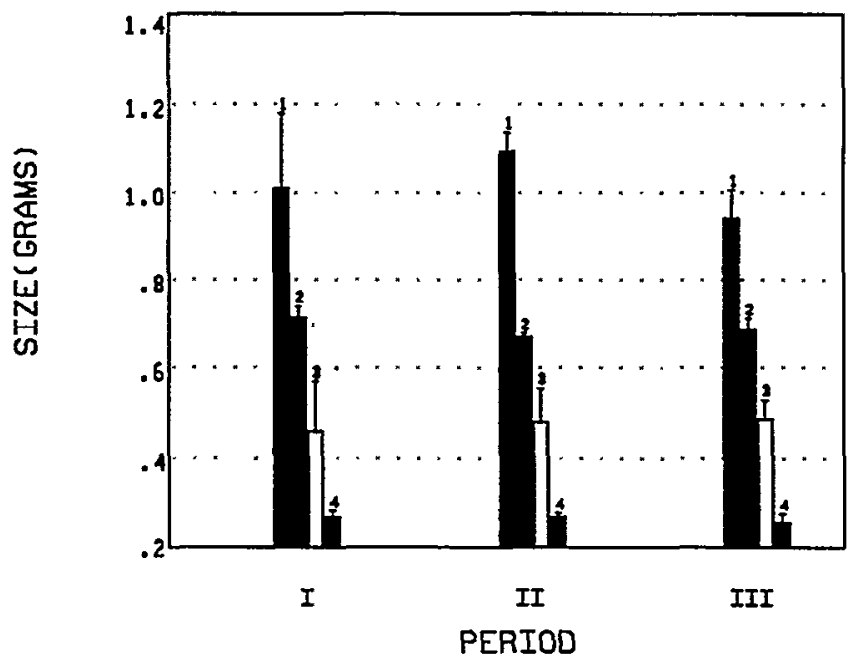

1 = browse bites for 1st feeding bout.

2 = browse strips.

3 = browse bites after lst feeding bout.

4 = grass bites.

Fig. 2. Average bite size for muskoxen feeding on grass and browse by period and bite class, Palmer, Alaska, 1992. treatment animals fed almost exclusively on browse, taking only the "most available" material from each bundle. Following this feeding bout, browse bite size stayed fairly constant for the remainder of the 8-hour period. Browse strips were intermediate in size between first bout and later browse bites. Grass bites were smaller than all bite classes of browse. Browse bite rate varied inversely with bite size, with the exception of strips (Fig. 3). Bitc rate for grass, in both treatments, was faster than that for browse bites or strips. Rates remained relatively constant among periods.

\section{Intake}

Intake rate for browse bites and strips was higher during the first trial hour (Fig. 4). Intake rates for grass in both treatments were higher than for all browse bites and strips except for that of browse bites in the first hour. The grass/browse treatment had a higher average intake value $(P=0.064)$ than the grass treatment (Fig. 5). The period effect for intake was also significant $(\mathrm{P}=$ $0.009)$, while the period-by-treatment interaction was not $(P=$ 0.130 ). The grass/browse treatment animals consumed 72.2 ( $\mathrm{SE}=$ 4.96), $65.8(\mathrm{SE}=2.19)$, and 62\% ( $\mathrm{SE}=5.81)$ of their diet as browse (on a dry-weight basis) in periods 1,2 , and 3 , respectively. The quantity of browse consumed varied by day within period $(P=0.075)$, animal within pasture $(P=0.082)$, and period $(p<$ 0.001 ) with less browse being consumed in period 3 than in periods 1 and 2 .

\section{Nutrition}

Willow, grass, and the composite diets showed little change in crude protein (CP) values over time (Table 2). Maintenance CP requirements for muskoxen are currently unknown. In vitro dry matter digestibility (IVDMD) values for willow and grass (Table 2) were similar for all collection periods, and neither showed a definite trend over time. The composite diets also showed no trend in IVDMD, over time, but were markedly higher than either grass or willow, at all collection periods. Neutral detergent fiber (NDF) was always lower for willow than grass, while composite diets had values intermediate between the two. Neither grass nor willow showed a strong trend in NDF values over time.

Table. 2. Characteristics (percent of dry matter) of forages consumed by muskoxen during the pasture browse trials, Palmer, Alaska, 1992.

\begin{tabular}{|c|c|c|c|c|c|c|c|c|}
\hline Item & Date & IVDM & $\mathrm{CP}$ & NDF & ADF & Lignin & $\mathrm{CCC}$ & NDF:CC \\
\hline Willaw & \multicolumn{8}{|c|}{ (n) } \\
\hline & $7-15$ & 43.2 & 12.5 & 41.4 & 23.4 & 0.0 & 58.6 & 0.71 \\
\hline & $8-1$ & 43.1 & 14.5 & 40.4 & 25.0 & 11.4 & 59.6 & 0.68 \\
\hline & $9-1$ & 42.4 & 11.6 & 38.3 & 24.9 & 11.7 & 61.8 & 0.62 \\
\hline \multicolumn{9}{|l|}{ Grass } \\
\hline & $7-15$ & 44.1 & 10.1 & 57.0 & 35.6 & 3.8 & 43.0 & 1.33 \\
\hline & $8-1$ & 43.7 & 15.7 & 53.3 & 34.0 & 1.5 & 46.7 & 1.14 \\
\hline & $9-1$ & 43.4 & 14.9 & 55.2 & 31.3 & 3.7 & 44.8 & 1.23 \\
\hline \multicolumn{9}{|c|}{ Willow:Grass } \\
\hline $\begin{array}{l}\text { P I } \\
(65: 35)\end{array}$ & $7-15$ & 57.0 & 11.7 & 46.9 & 27.6 & 7.8 & 53.1 & $0.8 s$ \\
\hline $\begin{array}{l}\text { P II } \\
(67: 33)\end{array}$ & $8-1$ & 50.9 & 14.9 & 44.6 & 28.0 & 8.1 & 55.4 & 0.81 \\
\hline $\begin{array}{l}\text { P III } \\
(62: 38)\end{array}$ & $9-1$ & 57.8 & 12.9 & 44.7 & 27.3 & 8.6 & 55.3 & 0.81 \\
\hline
\end{tabular}

aIVDMD, in vitro dry matter digestibility; $\mathrm{CP}$, crude protein: NDF, neutral detergent fiber, $A D F$, acid detergent fiber, $C C$, cell contents. 


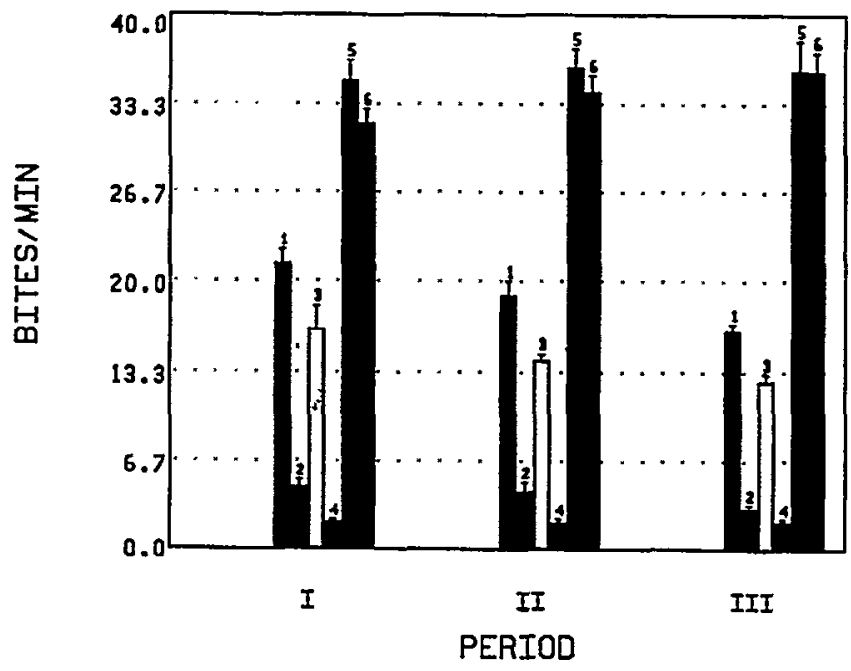

$1=$ browse bites for 1st feeding bout.

$2=$ browse strips for 1 st feeding bout .

$3=$ browse bites after lst feeding bout .

4 = browse strips after 1st feeding bout.

5 = grass bites for grass/browse treatment.

6 = grass bites for grass treatment.

Fig. 3. Average bite rate for muskoxen feeding on grass and browse by period and bite class, Palmer, Alaska, 1992.

\section{Discussion}

Feeding time (Fig. 1 and Table 1) is greater than that reported for free-ranging muskoxen in northern Alaska, which spent $34 \%$ (bulls) and $37 \%$ (cows) of their total time feeding (mid-summer), respectively (Jingfors 1981). Lesser day length in southern

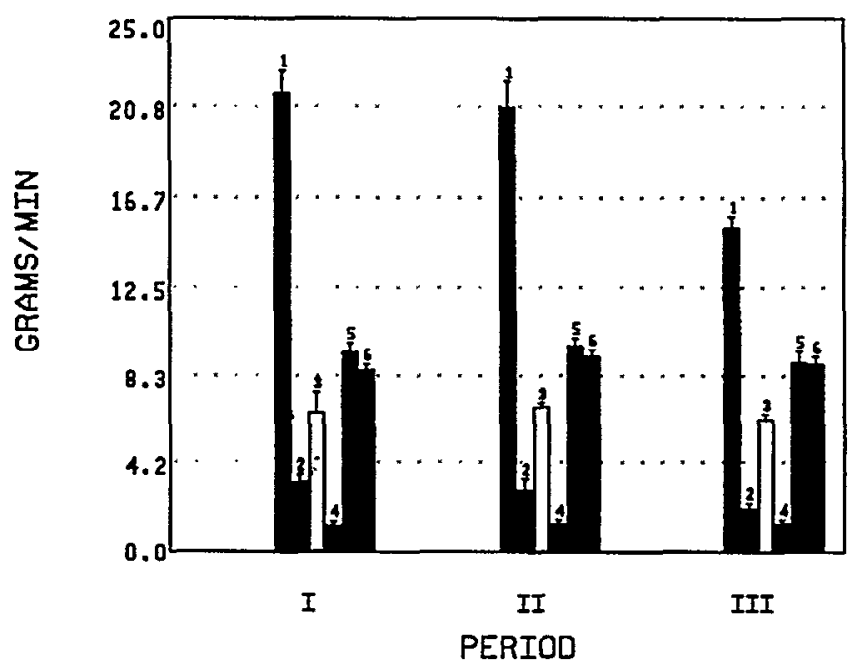

$I=$ browse bites for 1st feeding bout.

2 = browse strips for lst feeding bout

3 = browse bites after 1st feeding bout.

4 = browse strips after ist feeding bout.

$\mathbf{5}=$ grass bites for grass/browse treatment.

6 = grass bites for grass treatment.

Fig. 4. Average rate of intake for muskoxen feeding on grass and browse by period and bite class, Palmer, Alaska, 1992.

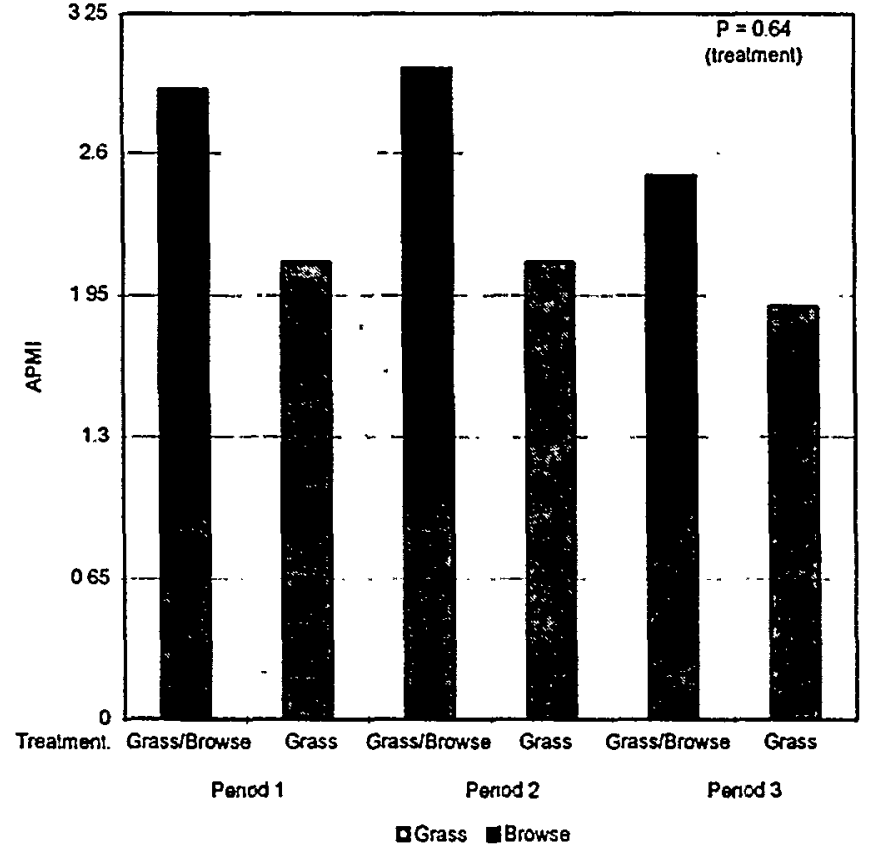

Fig. 5. Average 8-hour intake for muskoxen feeding on grass and browse by treatment and period, expressed as average percent of metabolic weight (body weight ${ }^{75}$ ) intake (APMI) on a dry-weight basis, Palmer, Alaska, 1992.

Alaska may have stimulated our animals to spend a greater percentage of daylight hours feeding.

Decline in browse feeding time in period 3 (Fig. 1) may have resulted from decreased palatability associated with leaf aging. Although still green, late season leaves had a noticeably drier texture. Lack of significant difference in rumination time between treatments contrasts with reports that rumination time increases in proportion to dietary fiber concentration (Robbins 1983, Van Soest 1987). However, the work of Spalinger et al. (1986) and Baker and Hobbs (1987) suggests that lignin may be a deterrent to particle breakdown and, thus, the high lignin content of the composite diets may increase the need for mastication. It is also possible that nocturnal rumination patterns may differ from those observed during the 8 -hour trial period.

Bite sizes (Fig. 2), bite rates (Fig. 3), and rates of intake (Fig. 4) are comparable to those of similar-sized North American ungulates consuming like forage classes (Collins et al. 1978, Trudell and White 1981, Wickstrom et al. 1984). The larger browse bite size for animals in the grass/browse treatment during the first feeding bout was probably a result of high preference, and the anticipation of receiving a highly preferred food item, at a set time, on a daily basis. Although browse was not limiting (i.e. browse was still available at the end of each 8-hour trial), declines in rate of browse intake and bite size within a trial day may have been influenced by a declining browse supply. In contrast, the size of browse strips did not perceptibly change during a given trial day. The relative uniformity of grass bite sizes and rates, over periods, resulted from phenological homogeneity of the trial pastures among trial periods. This trend was also apparent in the rather static nutritional values for grass (Table 2).

Higher average intake values for the grass/browse treatment (Fig. 5) were a function of a higher average intake rate and, in 
period 3, increased total foraging time. Decline in browse intake in period 3 was probably related to decreases in animal acceptance of browse as senescence progressed. The lack of a treatment by period interaction for intake is likely due to a low sample size per treatment, which reduced the power of the ANOVA model to detect significant differences.

Although increased intake values for the grass/browse treatment may be related to animal preference for browse vs. grass, they may also be correlated with the digestive properties of browse. Holleman et al. (1984) showed rate of passage in muskoxen was most rapid when both concentrate and roughage feeds were included in the diet. That is, a mix of fibrous and nonfibrous feeds was required for optimal rate of passage. This finding lends support to Hofmann's (1988) classification of the muskox as an intermediate forager.

Grass had a higher neutral detergent fiber (NDF) to cell contents ratio than browse (Table 2) at any time and, thus, when browse was added to the diet of the grass/browse treatment, composite values for NDF:cell contents decreased relative to grass. Lower NDF:cell contents ratios likely favored faster particle breakdown by rumen microflora for the grass/browse composite diet versus the grass diet. Short et al. (1974) demonstrated a faster rate of particle breakdown for current annual growth of browse compared to grass, using a nylon bag technique with ruminally cannulated goats. Smith et al. (1972) found soluble dry-matter content (i.e. cell contents) to be the best predictor of rate of ruminal fermentation. Spalinger et al. (1986) reported direct correlations between decreasing cell wall thickness and increasing rate of particle breakdown, and that browse cell walls were typically thinner than those of grass. They also found an inverse correlation between NDF values and rate of ruminal fermentation as well as rate of passage in captive elk (Cervus elaphus Erxleben) and mule deer (Odocoileus hemionus Rafinesque).

Thus, as the NDF:cell contents ratio decreases, rate of passage can increase (Milchunas et al. 1978) allowing intake to also increase (Van Soest 1965). This model may be applicable to our data, in that dietary NDF:cell contents ratios decreased and intake increased when animals were given access to browse. Holechek and Vavra (1983) found that cattle increased their intake when maintained on range containing browse and forbs versus grass only.

Increased ROP could, however, be a detriment in that in vivo digestibility may be lowered with increasing ROP (Huston et al. 1986, Robbins 1993). But, if rate of passage increased concurrently with dry-matter intake and dietary fermentation rate, then rate of nutrient aquisition per unit of time may be increased (Robbins 1993). Consequently, in vitro digestibilities we observed (Table 2) may not be representative of the relative value of the forages in relation to rate of nutrient aquisition. Additionally, since the inoculum donor was not maintained on a browse diet, its microbial population may not have been adapted to digestion of the browse component (Robbins et al. 1975). Animals receiving browse generally had very loose feces for about the first 5 days of adaptation, indicating that such a microbial adaptation may have been necessary.

The magnitude of difference in IVDMD values between composite diets, and willow and grass (Table 2), was somewhat unexpected. However, the higher values of composite diets could be indicative of an in vitro associative effect between grass and browse. Faster rate of fermentation and higher cell contents values (i.e. greater quantity of readily available nutrients) of browse may have increased rate of nutrient aquisition for microbes, causing irruptive microbial populations thereby increasing digestion of the total diet. Jones et al. (1988) reported increased in vivo organic matter digestion of orchard grass with the addition of ground corn fed at $0.5 \%$ of body weight daily. Mould et al. (1983) found that in vivo digestion of grass hay:barley diets increased linearly as a function of percent barley, when sheep on fixed hay rations were given ad libitum access to barley.

It should be noted that the intake and activity values from the 8-hour trials were assumed to be a qualitatively representative measure of intake and activity patterns, between treatments, on a 24-hour cycle. Although quantification of this assumption was not formally undertaken, nighttime observations made during period 3 indicated greater nocturnal feeding time for the grass/browse animals, but feeding activity decreased for both treatments relative to that measured during daytime trials.

In summary, we observed that pastured animals with access to browse had significantly higher intakes than animals pastured on grass alone. Higher intakes were a product of increased rates of intake during the first feeding bout of trials and, during period 3, more time spent feeding. The digestive physiology of muskoxen apparently favors higher intake of a mixed grass-browse diet than grass alone. Boyd (1993) reported that increased intake has potential to elevate animal performance relative to weight gain and qiviut growth.

\section{Literature Cited}

Altmann, J. 1974. Observational study of behavior: Sampling methods. Behav. 46:227-267.

Baker, D.L. and N.T. Hobbs. 1987. Strategies of digestion: digestive efficiency and retention time of forage diets in montane ungulates. Can. J. Zool. 65:1978-1984.

Bos G.N. 1967. Range types and their utilization by muskox on Nunivak Island, Alaska. M.S. Thesis, Univ. of Alaska, College.

Boyd, C.B. 1993. Evaluating the importance of browse in the summer diets of muskoxen pastured in south-central Alaska. M.S. Thesis, Utah State Univ. Logan, Ut.

Collins, W.B., P.J. Urness, and D.D. Austin. 1978. Elk diets and activities on different lodgepole pine habitat segments. J. Wildl. Manage. 42:799-810.

Cook, C.W. 1972. Comparative nutritive values of forbs, grasses and shrubs, p. 303-311. In: Wildland Shrubs-Their Biology and Utilization. USDA Forest Serv. Tech. Rep. INT-1.

Gunn, A. 1982. Muskox, p. 1025-1035. In: J.A. Chapman and G.A.Feldhammer (eds), Wild mammals of North America. Johns Hopkins Univ. Press, Baltimore, Md.

Hach, C.C., S.V. Brayton, and A.B. Kopelove. 1985. A powerful kjeldahl nitrogen method using peroxymonosulfuric acid. J. of Agr. and Food Chem.33:1117-1123.

Hofmann, R.R. 1988. Anatomy of the gastro-intestinal tract, p. 14-22. In: D.C. Church (ed), The ruminant animal,digestive physiology and nutrition. Prentice-Hall, Englewood Cliffs, N.J.

Holechek, J.L. and M. Vavra. 1983. Drought effects on diet and weight gains of yearling heifers in northeastern Oregon. J. Range Manage. 36:227-231.

Holleman, D.F., R.G. White, K. Frisby, M. Jourdan, P. Henrichsen, and P.G. Tallas. 1984. Food passage rates in captive muskoxen as measured with non-absorbed radiolabled markers. p. 188-192. In: Proceedings Of The First International Muskox Symposium, Univ, of Alaska, Fairbanks. Alaska.

Huston, J.E., B.S. Rector, W.C. Ellis, and M.L. Allen. 1986. Dynamics of digestion in cattle, sheep, goats and deer. J. Anim. Sci. 62:208-215. 
Jingfors, K.T. 1981. Habitat relationships and activity patterns of a reintroduced Alaskan muskox population. M.S. Thesis, Univ. Alaska, Fairbanks. Alaska.

Jones, A.L., A.L. Goetsch, S.R. Stokes and M. Colberg. 1988. Intake and digestion in cattle fed warm-or cool-seasongrass hay with or without supplemental grain. J. Anim. Sci. 66:194-203.

Milchunas, D.G., M.I. Dyer, O.C. Wallmo, and D.E. Johnson.1978. In vivo/invitro relationship of Colorado mule deer forages. O.B. Lope. ed. Colorado Div. Wildl. WRS-43.

Moore, J.E. 1970. Procedure for the two-stage in vitro digestion of forages. Univ. of Florida, Dept. of Anim. Sci. Gainsville, Fla.

Mould, F.L., E.R. Orskov, and S.A. Gauld. 1983. Associative effects of mixed feeds. II. The effect of dietary addition of bicarbonate salts on the voluntary intake and digestibility of diets containing various proportions of hay and barley. Anim. Feed Sci. and Tech. 10:31-47.

National Research Council. 1974. Nutrient requirements of beef cattle. Nat. Acad. Sci.-Nat. Res. Counc. 6th Rev.

Robbins, C.T. 1983. Wildlife feeding and nutrition. Academic Press, N.Y.

Robbins, C.T. 1993. Wildlife feeding and nutrition, 2nd Ed. Academic Press, N.Y.

Robbins, C.T. and P.J. Van Soest, W.W. Mauntz, and A.N. Moen. 1975. Feed analysis and digestion with reference to white-tailed deer. J. Wildl. Manage. 39:67-79.

Robus, M.A. 1981. Muskox habitat and use patterns in northeastern Alaska. M.S. Thesis, Univ. Alaska, Fairbanks. Alaska.

SAS Institute Inc. 1987. SAS/STAT TM ${ }^{\mathrm{TM}}$ guide for personal computers, version 6 ed. SAS Institute Inc., Cary, N.C.
Short, H.L., R.M. Blair, and C.A. Seqelquist. 1974. Fiber composition and forage digestibility by small ruminants. J. Wildl. Manage. $38: 197-202$.

Smith, L.W., H.K. Goering, and C.H. Gordon. 1972. Relationships of forage compositions with rates of cell wall digestion and indigestion and indigestibility of cell walls. J. Dairy Sci. 55:1140-1147.

Spalinger, D.E., C.T. Robbins, and T.A. Hanley. 1986. The assessment of handling time in ruminants: the effect of plant chemical and physical structure on the rate of breakdown of plant particles in the rumen of mule deer and elk. Can. J. Zool. 64:312-321.

Tener, J.S. 1965. Muskoxen in Canada. Dept of Northern Affairs and Nat. Resour., Can. Wildl. Serv. Monogr. Ser. No. 2., Queens printer. Ottawa.

Trudell, J. and R.G. White. 1981. The effect of forage structure and availability on food intake, biting rate, bite size and daily eating time of reindeer. J. Appl. Ecol. 18:63-91.

Van Soest, P.J. 1965. Voluntary intake in relation to chemical composition and digestibility: symposium on factors influencing the voluntary intake of herbage by ruminants. J. Anim. Sci. 24:834-843.

Van Soest, P.J. 1970. Forage fiber analysis. Agri. Handbook No. 379, USDA. U.S. Government Printing Office, Washington, D.C.

Van Soest, P.J. 1987. Nutritional ecology of the ruminant. O and B Books, Inc., Corvallis, O.R.

Wickstrom, M.L., C.T. Robbins, T.A. Hanley, D.E. Spalinger, and S.M Parish. 1984. Food intake and foraging energetics of elk and mule deer. J. Wildl Manage. 48:1285-1301.

\section{Statement of Ownership, Management, and Circulation}

(Act. of August 12, 1970, Sec. 3685, Title 39, United States Code)

1. Title of Publication: Journal of Range Management

2. Date of Filing: September 30, 1995

3. Frequency of /ssue: Bimonthly

4. Location of Office of Publication: 1839 York Street, Denver, Colo. 80206

5. Location of General Business Office: Same

6. Name and Address of:

Publisher: Society for Range Management, 1839 York Street, Denver, Colo. 80206

Editor: Gary Frasier, 8032 Glade Road, Loveland, Colo. 80538

Managing Editor: Dr. Charles Rumburg, 1839 York Street, Denver, Colo. 80206

7. Owner: Society for Range Management, 1839 York Street, Denver, Colo. 80206

8. Known Bondholders, Mortgages, etc.: Membership

9. For Completion by Nonprofit Organizations Authorized to Mail at Special Rates: The purpose, function, and nonprofit status of this organization and the exempt status for Federal income tax purposes have not changed during preceding 12 months.

10. Extent and Nature of Circulation

$\begin{array}{lcc}\text { A. Total copies printed } & 5,111 & 5,074 \\ \text { B. Paid Circulation } & & \\ \text { 1. Dealers, counter sales } & 0 & 0 \\ \text { 2. Mail subscriptions } & 4,602 & 4,641 \\ \text { C. Total paid circulation } & 4,602 & 4,641 \\ \text { D. Free distribution } & 15 & 15 \\ \text { E. Total distribution } & 4,617 & 4,656 \\ \text { F. Copies not distributed } & 494 & 418 \\ \text { G. Total } & 5,111 & 5,074\end{array}$

Actual for

issue nearest

filing date

641

15

4,656

5,074

I certify that the statements made by me above are correct and complete-Charles $B$. Rumburg, Managing Editor. 